\title{
Avian flu centre put under threat of closure
}

The Indonesian government has ordered a US military research unit in Jakarta - a key player in the fight against avian flu - to cease all research by 31 December. If the unit closes, researchers say, it would be a major blow to efforts to control the avian flu outbreaks currently affecting humans and poultry across the country.

The US Naval Medical Research Unit No. 2 (NAMRU-2) was set up in Indonesia in 1970 under a bilateral agreement with the United States. But the Indonesian military has been opposed to the centre's presence since the imposition of a US arms embargo in 1999. This followed violence involving the army during Indonesia's withdrawal from the newly independent East Timor.

NAMRU-2 has been working with the country's authorities to improve their ability to monitor and diagnose avian flu (see C. G. Beckett et al. Clin. Infect. Dis. 39, 443-449; 2004). Its crucial role is internationally recog- nized, particularly as Indonesia, where human cases were first reported in July, accounts for the world's largest share of new cases.

Although the centre's original agreement with Indonesia expired on January 2000, until recently the government had turned a blind eye to its continued operation. But on 23 November, Indonesiảs health ministry posted a memo on its website, dated 25 October, stating that "all NAMRU-2 activities must end by 31 December $2005^{\circ}$, and not be restarted without a new formal agreement. The memo was addressed to all health agencies and hospitals.

Researchers associated with the centre, who requested anonymity, are taking this threat very seriously. "We take the memo as representing Indonesian government policy, and its statement is very clear," says one scientist.

The researchers had believed the future was clearer following a visit to Indonesia by the US health secretary Michael Leavitt in midOctober. Leavitt was on a whirlwind tour of
Asian countries to bolster belated US efforts to build an international coalition against avian flu. He visited NAMRU-2, and promised it US $\$ 10$ million in extra funding .

That the health ministry's memo should appear following Leavitt's visit points to internal government power-play, says one scientist, adding that on 16 November they had been privately assured by Dino Djalal, one of the Indonesian president's chief advisers, that the centre would be allowed to continue.

"If this is my government's policy then they must have their reasons," says Sardikin Giriputro, deputy director of the Sulianti Saroso Infectious Disease Hospital in Jakarta, which treats most of the country's avian flu victims. "I have enjoyed a lot of benefits and cooperation with NAMRU-2 - it would be a great pity if its activities were stopped."

The World Health Organization declined to comment on the development.

Declan Butler 